\title{
A degenerate PCR-based strategy as a means of identifying homologues of aminoglycoside and $\beta$-lactam resistance genes in the gut microbiota
}

Fiona Fouhy ${ }^{1,2}$, R Paul Ross ${ }^{1,3}$, Gerald F Fitzgerald ${ }^{2,3}$, Catherine Stanton ${ }^{1,3}$ and Paul D Cotter ${ }^{1,3^{*}}$

\begin{abstract}
Background: The potential for the human gut microbiota to serve as a reservoir for antibiotic resistance genes has been the subject of recent discussion. However, this has yet to be investigated using a rapid PCR-based approach. In light of this, here we aim to determine if degenerate PCR primers can detect aminoglycoside and $\beta$-lactam resistance genes in the gut microbiota of healthy adults, without the need for an initial culture-based screen for resistant isolates. In doing so, we would determine if the gut microbiota of healthy adults, lacking recent antibiotic exposure, is a reservoir for resistance genes.

Results: The strategy employed resulted in the identification of numerous aminoglycoside (acetylation, adenylation and phosphorylation) and $\beta$-lactam (including bla $a_{\mathrm{OXA}}, b / a_{\mathrm{TEM}}, b / a_{\mathrm{SHV}}$ and $b / a_{\mathrm{CTX}-\mathrm{M}}$ ) resistance gene homologues. On the basis of homology, it would appear that these genes originated from different bacterial taxa, with members of the Enterobacteriaceae being a particularly rich source. The results demonstrate that, even in the absence of recent antibiotic exposure, the human gut microbiota is a considerable reservoir for antibiotic resistance genes.

Conclusions: This study has demonstrated that the gut can be a significant source of aminoglycoside and $\beta$-lactam resistance genes, even in the absence of recent antibiotic exposure. The results also demonstrate that PCR-based approaches can be successfully applied to detect antibiotic resistance genes in the human gut microbiota, without the need to isolate resistant strains. This approach could also be used to rapidly screen other complex environments for target genes.
\end{abstract}

Keywords: Antibiotic resistance, Aminoglycosides, $\beta$-lactam, Gut microbiota, PCR

\section{Background}

Almost as soon as the widespread therapeutic use of antibiotics occurred, bacteria displaying diverse and complex mechanisms of resistance became problematic $[1,2]$. As the human gut is one of the most densely populated microbial environments, it has been postulated that it can act as a considerable reservoir for antibiotic resistance genes [3]. Thus, gut microbes may disseminate antibiotic resistance genes to other commensals or to bacteria transiently colonising the gut [4]. Given that antibiotics are known to exert significant and sustained negative effects on the gut microbiota [5,6], possessing resistance genes can provide a significant selective advantage to a subpopulation

\footnotetext{
* Correspondence: paul.cotter@teagasc.ie

${ }^{1}$ Teagasc Food Research Centre, Moorepark, Fermoy, Cork, Ireland

${ }^{3}$ Alimentary Pharmabiotic Centre, Cork, Ireland

Full list of author information is available at the end of the article
}

of microorganisms in individuals undergoing antibiotic treatment [7]. The aminoglycosides and $\beta$-lactams are two large families of antibiotics which are frequently employed in clinical settings. The aminoglycosides, which were first characterised in 1944, [8] function by binding to the $30 \mathrm{~S}$ subunit of the prokaryotic ribosome resulting in disruption to protein synthesis. Resistance to aminoglycosides can be through reduced aminoglycoside uptake or enzymatic modification of the aminoglycoside through acetylation (AAC), adenylation (ANT) or phosphorylation (APH). $\beta$-lactam antibiotics include the penicillins and cephalosporins and inhibit bacteria through disruption of cell wall biosynthesis $[9,10]$. Resistance to $\beta$-lactams can be due to alterations to penicillin binding proteins or to the porins in the outer membrane (in Gram negative targets) or alternatively through the production of $\beta$-lactamases,

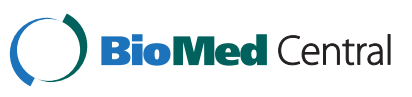


which hydrolyse the eponymous $\beta$-lactam ring rendering the antibiotic inactive $[11,12]$.

The question of the evolutionary origin of antibiotic resistance genes has been the subject of much attention $[9,13,14]$. For quite some time it was thought that resistance evolved following exposure of bacteria to new antibiotics [15]. However, it is now apparent that repositories of antibiotic resistance genes exist such that, following the development and application of new antibiotics, bacteria possessing or acquiring such genes will gain a selective advantage and thus resistance will increase over time $[16,17]$. Previous studies have employed PCR to detect resistance genes in specific pathogens $[18,19]$, though studies employing PCR to detect resistance genes in complex microbial environments have been limited. In one instance, a PCR-based approach was used to investigate the prevalence of gentamycin resistance genes in resistant isolates from sewage, faeces (from cattle and chickens), municipal and hospital sewage water and coastal water [20]. The utilisation of a PCR approach in that instance resulted in the identification of diverse genes encoding gentamycin modifying enzymes from across a broad host range, thus demonstrating the suitability of a PCR-based approach to investigate resistance genes present in complex environments. However, the study did not investigate antibiotic resistance genes in human gut microbiota and, to our knowledge, to date no such PCR-based studies exist. Given these findings and other indications that there exist large natural pools of antibiotic resistance genes within complex microbial populations, it is likely that the human gut also contains many such genes. However, until now, PCR-based strategies to detect antibiotic resistance genes in the gut microbiota have involved an initial culture-based screen for resistant isolates, followed by subsequent PCR-based approaches to identify the associated resistance genes. This does not take into consideration the fact that the vast majority of gut microbes are not easily cultured [21], and thus antibiotic resistance genes from such microorganisms would typically be overlooked.

Here we utilise degenerate PCR primers to investigate the presence of $\beta$-lactam resistance genes and each of the three categories of aminoglycoside modifying enzymes within human metagenomic DNA and in doing so demonstrate that the human gut microbiota is a reservoir for antibiotic resistance genes. Additionally, we establish that a PCR-based approach allows the rapid detection of such genes in the complex gut microbiota environment, without the need for an initial isolation of strains.

\section{Methods}

\section{Recruitment of volunteers}

Forty adults were recruited and each provided written, informed consent for participation in this study. Approval for this trial was received from the Clinical Research
Ethics Committee of the Cork Teaching Hospitals, Cork, Ireland. Volunteers were aged $28.8 \pm 3.8$ years, were free from gastrointestinal disorders and had not been treated with antibiotics in the 6 months prior to sample collection. Fresh faecal samples were collected and stored at $-80^{\circ} \mathrm{C}$ until processed.

\section{DNA extraction}

Stool samples were weighed, homogenised and due to the total volume provided by each individual, samples had to be pooled to achieve the required volume for our metagenomic DNA extraction protocol. To facilitate this, an equal volume $(250 \mathrm{mg}$ ) from each individual was taken and pooled to form one sample, from which metagenomic DNA was extracted. The DNA extraction procedure used was optimised for total bacterial genomic DNA extraction from stool samples. The stool sample was homogenized in PBS and centrifuged at $1000 \mathrm{~g} \times 5$ mins and the supernatant was removed and retained. This was repeated 3 times. The supernatant then underwent Nycodenz (Axis Shield, UK) density gradient centrifugation separation, to separate out the bacterial cells from faecal matter. Following enzymatic lysis of bacterial cells using lysozyme and mutanolysin (Sigma Aldrich, Dublin, Ireland) protein precipitation using Proteinase $\mathrm{K}$ and ammonium acetate (Sigma Aldrich) was completed. Bacterial DNA was then precipitated and washed using standard chloroform and ethanol procedures. DNA was eluted in TE buffer.

\section{PCR-based detection of $\beta$-lactam resistance gene homologues}

PCR-based detection of $\beta$-lactam resistance genes was completed using primers (MWG Eurofins, Germany) for the genes bla $a_{\mathrm{TEM}}$ [22,23], bla $a_{\mathrm{SHV}}$ [24] (both of which are classified as Bush group 2b $\beta$-lactamases), bla ${ }_{\text {CтХ-M }}[25]$ (an extended spectrum $\beta$-lactamase (ESBL) which confers resistance to cefotaxime), bla $a_{\text {OXA }}$ [24] (ESBL, Bush group $2 \mathrm{~d}$ ESBL) and bla $a_{\mathrm{ROB}}$ [23] (confers high level ampicillin resistance) (Table 1). PCRs were completed using bacterial metagenomic DNA and all PCRs were performed in triplicate. PCRs were completed on a G-storm PCR machine and for the primer sets $b l a_{\mathrm{TEM}}$ primer set 1 (RH605/606), $b l a_{\text {TEM }}$ primer set 2 and $b l a_{\text {CTX-M }}$, PCRs were completed as previously outlined. For the primers $b l a_{\mathrm{OXA}}$ and $b l a_{\mathrm{ROB}}$ the PCR conditions were as follows: heated lid $110^{\circ} \mathrm{C}$, $94^{\circ} \mathrm{C} \times 5$ mins followed by 30 cycles of $94^{\circ} \mathrm{C} \times 30$ s, $64^{\circ} \mathrm{C} \times$ $30 \mathrm{~s}\left(b l a_{\text {oxa }}\right)$ or $62^{\circ} \mathrm{C}\left(b l a_{\mathrm{ROB}}\right)$ and $72^{\circ} \mathrm{C} \times 30$ s followed by $72^{\circ} \mathrm{C} \times 10$ mins and held at $4^{\circ} \mathrm{C}$. For bla $a_{\text {SHV }}$ PCRs were performed as follows: heated lid $110^{\circ} \mathrm{C}, 94^{\circ} \mathrm{C} \times 5$ mins followed by 35 cycles of $94^{\circ} \mathrm{C} \times 30 \mathrm{~s}, 58^{\circ} \mathrm{C} \times 30 \mathrm{~s}$ and $72^{\circ} \mathrm{C} \times 30$ s followed by a final extension step of $72^{\circ} \mathrm{C} \times 10$ mins and held at $4^{\circ} \mathrm{C}$. All PCRs contained $25 \mu$ l Biomix Red (Bioline, UK), $1 \mu \mathrm{l}$ forward primer (10pmol concentration), $1 \mu \mathrm{l}$ reverse primer (10pmol concentration), 
Table 1 Primers used for the detection of $\beta$-lactamase and aminoglycoside resistant genes

\begin{tabular}{|c|c|c|c|c|c|}
\hline Location & Primer & Sequence $5^{\prime}-3^{\prime}$ & Amplicon Size (bp) & Annealing $\operatorname{Temp}^{\circ} \mathrm{C}$ & Source \\
\hline \multicolumn{6}{|l|}{$\beta$-lactamase genes } \\
\hline \multirow[t]{4}{*}{$B l a_{\text {TEM }}$} & $\mathrm{RH} 605$ & TTCGTGTCGCCCTTATTCC & 692 & 60 & Bailey et al. (2011) [22] \\
\hline & RH606 & CCGGCTCCAGATTTATCAGC & & & \\
\hline & Bla_TEMF & TGGGTGCACGAGTGGGTTAC & 526 & 57 & Tenover et al. (1994) [23] \\
\hline & Bla_TEMR & TTATCCGCCTCCATCCAGTC & & & \\
\hline \multirow[t]{2}{*}{$B l a_{\mathrm{ROB}}$} & Bla_ROBF & ATCAGCCACACAAGCCACCT & 692 & 62 & Tenover et al. (1994) [23] \\
\hline & Bla_ROBR & GTTGCGATTTGGTATGCGA & & & \\
\hline \multirow[t]{2}{*}{$B l a_{\mathrm{SHV}}$} & Bla_SHVF & CACTCAAGGATGTATTGTG & 885 & 58 & Briñas et al. (2002) [24] \\
\hline & Bla_SHVR & TTAGCGTTGCCAGTGCTCG & & & \\
\hline \multirow[t]{2}{*}{ Bla OXA } & Bla_OXAF & TTCAAGCCAAAGGCACGATAG & 702 & 64 & Briñas et al. (2002) [24] \\
\hline & Bla_OXAR & TCCGAGTTGACTGCCGGGTTG & & & \\
\hline \multirow[t]{2}{*}{$B / a_{C T X-M}$} & Bla_CTX-MF & CGTTGTAAAACGACGGCCAGTGAATGTGCAGYACCAGTAARGTKATGGC & 600 & 55 & Monstein et al. (2009) [25] \\
\hline & Bla_CTX-MR & TGGGTRAARTARGTSACCAGAAYCAGCGG & & & \\
\hline \multicolumn{6}{|l|}{ AG resistant genes } \\
\hline \multirow[t]{2}{*}{$\operatorname{aac}(3)-1$} & Faac3-1 & TTCATCGCGCTTGCTGCYTTYGA & 239 & 58 & Heuer et al. (2002) [20] \\
\hline & Raac3-1 & GCCACTGCGGGATCGTCRCCRTA & & & \\
\hline \multirow[t]{4}{*}{$\operatorname{aac}(3)-\| / \mathrm{Vl}$} & Faac3-2 & GCGCACCCCGATGCMTCSATGG & 189 & 58 & \\
\hline & Raac3-2 & GGCAACGGCCTCGGCGTARTGSA & & & \\
\hline & Facc3-6 & GCCCATCCCGACGCATCSATGG & & & \\
\hline & Raac3-6 & CGCCACCGCTTCGGCATARTGSA & & & \\
\hline \multirow[t]{2}{*}{$a a c\left(6^{\prime}\right)-11 / 1 \mathrm{~b}$} & Faac6 & CACAGTCGTACGTTGCKCTBGG & 235 & 58 & \\
\hline & Raac6 & CCTGCCTTCTCGTAGCAKCGDAT & & & \\
\hline \multirow[t]{2}{*}{ ant $\left(2^{\prime}\right)-1$} & Fant & TGGGCGATCGATGCACGGCTRG & 428 & 58 & \\
\hline & Rant & AAAGCGGCACGCAAGACCTCMAC & & & \\
\hline \multirow[t]{3}{*}{ aph (2")-1 } & Faphc & CCCAAGAGTCAACAAGGTGCAGA & 527 & 55 & \\
\hline & Faphd & GGCAATGACTGTATTGCATATGA & 572 & 55 & \\
\hline & Raph & GAATCTCCAAAATCRATWATKCC & & & \\
\hline \multirow[t]{4}{*}{ aac (6')-le-aph (2")-la } & aac-aphF & GAGCAATAAGGGCATACCAAAAATC & 505 & 47 & De Fatíma Silva Lopes et al. (2003) [26] \\
\hline & aac-aphR & CCGTGCATTTGTCTTAAAAAACTGG & & & \\
\hline & aac6-aph2F & CCAAGAGCAATAAGGGCATACC & 222 & 55 & Schmitz et al. (1999) [27] \\
\hline & aac6-aph2R & CACACTATCATAACCATCACCG & & & \\
\hline
\end{tabular}


metagenomic DNA (64 ng) and PCR grade water (Bioline, $\mathrm{UK})$, to a final volume of $50 \mu \mathrm{l}$. Negative controls were completed for all primer sets. Gel electrophoresis was performed on all samples using $1.5 \%$ agarose gel in $1 \times$ TAE buffer.

\section{PCR-based detection of aminoglycoside resistance gene homologues}

For the detection of aminoglycoside resistant genes, degenerate primer sets were used which had previously been designed and shown to amplify all known genes encoding gentamycin-modifying enzymes and similar, but as yet undiscovered, sequences [20]. PCRs were completed using primer sets (MWG Eurofins, Germany) for genes belonging to each group of aminoglycoside modifying enzymes namely, acetylation, adenylation and phosphorylation enzymes. DNA from positive controls (kindly gifted to us from the Smalla laboratory, JKI, Braunschweig) namely Escherichia coli S17-1 pAB2002 (aac (3)-Ia), Pseudomonas aeruginosa $88.341 \mathrm{~F}$ (aac (3)-Ib), Enterobacter aerogenes 17798 VDK (aac (3)-IIa), E. coli DH5 $\alpha$ pSCH4203 (aac (3)-IIb), E. coli DH5a pSCH4101 (aac (3)-VIa), P. aeruginosa PST-1 (aac (3)-IIIa), Acinetobacter baumannii LBL.3 (aac (6')-Ib), P. aeruginosa F-03 (aac (6')-IIa), E. coli DH5 $\alpha$ pSCH5102 (aac (6')-IIb), E. coli CV600 pIE723 (ant (2")-I), E. coli DH5 $\alpha$ pAM6306 (aph (2")-Ic) and E. coli NC95 (aph (2")-Id) were used as positive controls for the PCR reactions. This ensured the specificity of the respective primer pairs. PCRs for the detection of acetylation genes $a a c$ (3)-I, $a a c$ (3)-II, $a a c$ (3)-III, $a a c$ (3)-VI and $a a c$ (6), adenylation genes ant (2")-Ia and phosphorylation genes aph (2")-Ic and aph (2")-Id were completed as previously outlined [20] (Table 1). Additionally, PCRs using primers for the bifunctional gene aac (6")-Ie-aph (2") [26,27] (which encodes enzymes responsible for high level gentamycin resistance, as well as concomitant resistance to tobramycin and kanamycin) [27-31] were completed as follows: heated lid $110^{\circ} \mathrm{C}, 94^{\circ} \mathrm{C} \times 5$ mins followed by 30 cycles of $94^{\circ} \mathrm{C} \times 30 \mathrm{~s}, 47^{\circ} \mathrm{C} \times 30 \mathrm{~s}, 72^{\circ} \mathrm{C} \times 30 \mathrm{~s}$, with a final extension step of $72^{\circ} \mathrm{C} \times 10$ mins and held at $4^{\circ} \mathrm{C}$. All PCRs contained $25 \mu \mathrm{l}$ Biomix Red (Bioline, UK), $1 \mu \mathrm{l}$ forward primer (10pmol concentration), $1 \mu \mathrm{l}$ reverse primer (10pmol concentration), metagenomic DNA (64 ng) and PCR grade water (Bioline, UK), to a final volume of $50 \mu \mathrm{l}$. Negative controls were run for all primer sets. All PCRs were performed in triplicate and analysed using gel electrophoresis, as described above.

\section{Cloning of PCR amplicons}

Triplicate samples from successful PCR reactions were pooled and cleaned using AMPure magnetic bead-based PCR clean up kit (Beckman Coulter, UK). TOPO cloning reactions were performed on purified PCR products using the TOPO TA cloning kit (Invitrogen, Dublin, Ireland) to facilitate the sequencing of individual gene fragments. TOPO cloning reactions were then cloned into TOP10 E. coli (Invitrogen) as per the manufacturer's instructions and plated onto LB (Difco) containing the appropriate antibiotic (either ampicillin $50 \mu \mathrm{g} / \mathrm{ml}$ or kanamycin $50 \mu \mathrm{g} /$ ml; Sigma Aldrich, Dublin, Ireland) to select for the presence of the cloning vector. Transformants were selected from each TOPO cloning reaction and grown overnight in LB broth containing the suitable selective antibiotic (either ampicillin $50 \mu \mathrm{g} / \mathrm{ml}$ or kanamycin $50 \mu \mathrm{g} / \mathrm{ml}$ ). Plasmids were extracted from overnight samples using QIAprep Spin Mini Prep kit (Qiagen, Sussex, UK) according to the manufacturer's instructions and sent for Sanger sequencing (Source BioSciences, Dublin, Ireland).

\section{Bioinformatic analysis}

Following Sanger sequencing, sequence reads were analysed using the NCBI protein database (BlastX; (http://blast.ncbi. nlm.nih.gov/)). In the event where multiple hits occurred, the BLAST hit which displayed greatest homology is reported.

\section{Results and discussion}

\section{A PCR-based approach highlights the presence of} $\beta$-lactamase gene homologues in the gut microbiota

The results of the $\beta$-lactamase-specific PCRs demonstrated the presence and diversity of class $2 \beta$-lactamase genes in the gut microbiota of healthy adults (Table 2 [32]). Of the $\beta$-lactam primers used, the primers designed to amplify $b l a_{\text {TEM }}$ genes yielded the greatest number of unique sequence hits ( $42 \%$ of selected TOPO sub-clones gave a unique hit). The majority of these genes exhibited a high percentage identity with genes from various members of the Proteobacteria including E. coli, Klebsiella, Salmonella, Serratia, Vibrio parahaemolyticus and Escherichia vulneris. The resistance of strains of Salmonella and Serratia to $\beta$-lactams via $b l a_{\text {TEM }}$ genes has been noted [33-35] and such strains have been associated with nosocomial infections [36]. In contrast, there have been relatively few studies of bla $a_{\mathrm{TEM}}$ genes in Vibrio parahaemolyticus and Escherichia vulneris [37,38]. The identification of genes homologous to those from Enterobacteriaceae is not surprising given the prevalence of resistance genes among members of this family [12]. It was notable that the bla $a_{\text {TEM }}$ primers also amplified genes that resembled $b l a_{\mathrm{TEM}}$ genes from some more unusual sources, including two genes from uncultured bacteria and from a Sar 86 cluster (a divergent lineage of $\gamma$-Proteobacteria) bacteria. This approach can thus provide an insight into possible novel/unusual sources of resistance genes, including those that culture-based approaches would fail to detect. Such results also highlight that had initial screening for resistant isolates been completed prior to PCR amplification of the resistance genes, such unusual sources of resistance genes may have been 
Table 2 Homologues of $\beta$-lactamase genes detected in the human gut microbiota via PCR techniques

\begin{tabular}{|c|c|c|c|c|}
\hline Accession \# & Gene description & Closest homologue & E value & $\%$ identity \\
\hline \multicolumn{5}{|l|}{$B l a_{\mathrm{TEM}}$} \\
\hline ADE18890.1 & $\beta$-lactamase TEM-1 & S. enterica subsp. enterica & $5 e^{-154}$ & 99 \\
\hline AAS46844.1 & $\beta$-lactamase TEM-1 & S. marcescens & $2 e^{-156}$ & 100 \\
\hline AEN02824.1 & $\beta$-lactamase TEM-1 & K. pneumoniae & $3 e^{-111}$ & 99 \\
\hline AEN02817.1 & $\beta$-lactamase TEM-1 & K. pneumoniae & $1 e^{-113}$ & 99 \\
\hline ACV88636.1 & $\beta$-lactamase TEM-1 & E. coli & $2 e^{-151}$ & 99 \\
\hline AEL87577.1 & ES $\beta$-lactamase TEM-116 & Vibrio parahaemolyticus & $5 e^{-154}$ & 99 \\
\hline AEQ55231.1 & $\beta$-lactamase TEM-1 & E. coli & $1 e^{-35}$ & 45 \\
\hline ABQ14376.1 & $\beta$-lactamase & Uncultured soil bacterium & $6 e^{-05}$ & 83 \\
\hline ADN79104.1 & $\beta$-lactamase TEM & Escherichia vulneris & $1 e^{-15}$ & 86 \\
\hline WP_010157942.1 & $\beta$-lactamase TEM & Sar 86 cluster bacterium & $9 e^{-122}$ & 83 \\
\hline ACI29961.1 & $\beta$-lactamase TEM-1 & E. coli & $2 e^{-153}$ & 99 \\
\hline AEQ39590.1 & $\beta$-lactamase TEM-195 & E. coli & $5 e^{-93}$ & 96 \\
\hline AAM22276.1 & $\beta$-lactamase TEM-96 & E. coli & $7 e^{-139}$ & 94 \\
\hline WP_019405145.1 & $\beta$-lactamase TEM & K. pneumoniae & $4 e^{-155}$ & 99 \\
\hline AEW28787.1 & $\beta$-lactamase TEM-1 & Uncultured bacterium & $1 e^{-133}$ & 100 \\
\hline ABY81267.1 & $\beta$-lactamase & E. coli & $4 e^{-156}$ & 100 \\
\hline AAF74292.1 & ES $\beta$-lactamase & E. coli & $5 e^{-155}$ & 99 \\
\hline AFU53026.1 & KPC-2 $\beta$ lactamase & S. marcescens & $2 e^{-112}$ & 98 \\
\hline ADE18896.1 & $\beta$-lactamase TEM-1 & Salmonella enterica & $2 e^{-113}$ & 99 \\
\hline AEN02826.1 & $\beta$-lactamase TEM-1 & K. pneumoniae & $4 e^{-113}$ & 99 \\
\hline \multicolumn{5}{|l|}{$B l a_{\mathrm{ROB}}$} \\
\hline YP_252228.1 & Hypothetical protein SH0313 & S. haemolyticus & $2 e^{-33}$ & 44 \\
\hline \multicolumn{5}{|l|}{$B l a_{\mathrm{SHV}}$} \\
\hline WP_009348253.1 & Hypothetical protein HMPREF 9332 & Alloprevotella rava & $3 e^{-07}$ & 56 \\
\hline WP_017896153.1 & $\beta$-lactamase & K. pneumoniae subsp. pneumoniae & 0.0 & 99 \\
\hline WP_008157744.1 & Hypothetical protein HMPREF 1077 & Parabacteroides johnsonii & 1.5 & 29 \\
\hline CAJ47138.2 & $\beta$-lactamase & K. pneumoniae & 0.0 & 99 \\
\hline ADU15837.1 & BlaSHV132 & K. pneumoniae & 0.0 & 99 \\
\hline AEK80394.1 & $\beta$-lactamase SHV140 & K. pneumoniae & 0.0 & 99 \\
\hline ABS72351.1 & $\beta$-lactamase SHV103 & K. pneumoniae & 0.0 & 99 \\
\hline AAP03063.1 & $\beta$-lactamase SHV48 & K. pneumoniae & 0.0 & 99 \\
\hline AEG79634.1 & ES $\beta$-lactamase SHV120 & E. coli & & 99 \\
\hline \multicolumn{5}{|l|}{$B l a_{\mathrm{CTX}-\mathrm{M}}$} \\
\hline ABG46354.1 & ES $\beta$-lactamase & E. coli & $3 e^{-139}$ & 99 \\
\hline AEZ49563.1 & $\beta$-lactamase CTX-M-1 & E. coli & $2 e^{-138}$ & 99 \\
\hline AEZ49551.1 & $\beta$-lactamase CTX-M-1 & K. pneumoniae & $1 e^{-139}$ & 100 \\
\hline ABG46356.1 & ES $\beta$-lactamase & K. pneumoniae & $9 e^{-139}$ & 97 \\
\hline ABW06480.1 & ES $\beta$ lactamase CTX-M-15 & K. pneumoniae & $6 e^{-51}$ & 94 \\
\hline AAB22638.1 & $\beta$-lactamase penicillin hydrolase & E. coli & $9 e^{-140}$ & 100 \\
\hline BAD16611.1 & $\beta$-lactamase CTX-M-36 & E. coli & $8 e^{-139}$ & 99 \\
\hline YP_003717483.1 & $\beta$-lactamase & E. coli & $2 e^{-139}$ & 100 \\
\hline ABN09669.1 & $\beta$-lactamase CTX-M-61 & S. enterica & $2 e^{-138}$ & 100 \\
\hline
\end{tabular}

ESBL: extended spectrum $\beta$-lactamase. Gene names are in bold. 
overlooked. Additionally, genes encoding ESBLs, including $b l a_{\mathrm{TEM}-116}, b l a_{\mathrm{TEM}-195}$ and $b l a_{\mathrm{TEM}-96}$ amongst others, were also identified, with their closest homologues being members of the Proteobacteria (Table 2).

Using the bla $a_{\mathrm{SHV}}$ primers, multiple genes sharing homology with genes from members of the Enterobacteriaceae, and Klebsiella and E. coli in particular were detected. In addition, amplicons with low percentage identity to genes from Alloprevotella rava and Parabacteroides johnsonii, respectively, were also identified. This is again consistent with existing research which states that Enterobacteriaceae are the primary source of bla $a_{\mathrm{SHV}}$ genes [39-43]. Furthermore, the amplicons sequenced resembled various different types of ESBL-encoding SHV genes, including $b a_{\mathrm{SHV}-132}$, $b l a_{\mathrm{SHV}-140}$ and $b l a_{\mathrm{SHV}-48}$, thus again highlighting the genuine degeneracy of the primers used.

Additional PCRs were completed to identify other ESBLs, specifically CTX-M- and OXA-type $\beta$-lactamases (Table 2 ). A number of different CTX-M $\beta$-lactamases were detected, including CTX-M-1, CTX-M-15 and CTX-M-36. The fact that many of the $\beta$-lactamase genes detected using our approach share homology with resistance genes found in members of the phylum Proteobacteria is not surprising as, despite being typically less common than the Bacteroidetes or Firmicutes in the gut microbiota of healthy adults [21], members of this genus have been identified as sources of antibiotic resistance genes and have been frequently associated with nosocomial infections and outbreaks $[36,39,44,45]$. In the 1990s, TEM- and SHV-type ESBLs were the $\beta$-lactamases most frequently observed among Enterobacteriaceae [18]. However, more recently, CTX-M-type ESBLs have spread rapidly and are now the most prevalent ESBL in Enterobacteriaceae in several parts of the world [46]. In a recent report on antibiotic resistance threats in the USA, the Centre for Disease Control stated that ESBL-producing Enterobacteriaceae were a serious public health threat [47]. The report estimates that 26,000 infections and 1,700 deaths that occur each year in the United States are attributable to ESBLs and that upwards of 140,000 health-care related Enterobacteriaceae infections occur annually. Therefore the detection of homologues of ESBL-encoding genes in the gut microbiota of healthy individuals is significant and provides evidence of the ubiquitous nature of these resistance genes, even in the absence of recent antibiotic exposure. With respect to the CTXM-type ESBLs, it is particularly notable that homologues of the $b l a_{\mathrm{CTX}-\mathrm{M}-15}$ gene were detected, as these have received significant attention due to their recent rapid spread and their association with multi-drug resistant E. coli responsible for outbreaks of antibiotic resistant infections $[48,49]$. In such cases, these genes have been found on multi-drug resistance-encoding regions of plasmids, thus facilitating the rapid transfer of these genes. The presence of such genes within the gut microbiota raises concerns that horizontal gene transfer may occur between commensals or to bacteria passing through the gut. If the resistance genes detected in our study are, or were to become, mobile, it would enable the gut to act not only as a source of resistance genes, but also as a site of resistance gene transfer. Although outside the scope of this study, studies investigating whether these genes are located on or near mobile genetic elements would be pertinent to ascertain the risk of the gut acting as a site for horizontal gene transfer.

When the bla $a_{\mathrm{ROB}}$ primer set was employed to detect the presence of homologues of these ampicillin resistanceencoding genes, all amplicons sequenced were identical and shared $44 \%$ identity to Staphylococcus haemolyticus $b l a_{\mathrm{ROB}}$ gene. Finally, this study did not detect $b l a_{\mathrm{OXA}}$ gene homologues in our metagenomic sample. These findings are unexpected and may have occurred as a result of the particular affinity of the primer sets used.

\section{A PCR-based approach highlights the presence of aminoglycoside resistance encoding gene homologues in the gut microbiota}

Degenerate primers were selected that amplify genes encoding aminoglycoside modifying enzymes from each of the enzyme modification groups, namely acetylation, adenylation and phosphorylation [32]. When primers were applied to detect acetylation-associated genes, it was established that the primers designed to target $a a c$ (3)-I, aac (3)-II, and aac (3)-III homologues did not generate amplicons. In each of these PCR reactions the positive controls successfully amplified, thus we are satisfied that the lack of amplification products for our metagenomic sample is a true result. However, a number of distinct aac (6) and aac (3)-VI homologues were detected and were found to resemble genes from a variety of genera, including Acinetobacter, Pseudomonas and Enterobacter (Table 3). The presence of aminoglycoside acetylation genes within these genera has been noted previously [50-53]. The detection of resistance genes resembling those seen in A. baumannii is a concern, as many strains of this species have been shown to exhibit multi-drug resistance $[54,55]$. In addition, homologues of genes from Collinsella and Salmonella were also detected. Primers designed to amplify bifunctional aac (6')-Ie-aph (2') genes were also employed. Our investigations revealed the presence of homologues of such genes, resembling those from S. aureus, E. faecium and S. epidermidis, all of which are known sources of these genes $[27,56,57]$.

Homologues of aminoglycoside phosphorylation-encoding genes were also detected using a PCR-based approach, with both aph (2")-Ic and aph (2")-Id like genes being detected. These genes shared homology with genes from Enterococcus species, including E. faecium and E. casseliflavus. Aminoglycoside resistant E. faecium have received 
Table 3 Homologues of aminoglycoside resistance genes detected in the human gut microbiota via PCR techniques

\begin{tabular}{|c|c|c|c|c|}
\hline Accession \# & Gene description & Closest homologue & E value & $\%$ identity \\
\hline \multicolumn{5}{|l|}{ aac (6) } \\
\hline AAA25680.1 & AG 6'-N-acetyltransferase & Pseudomonas fluorescens & $4 e^{-48}$ & 98 \\
\hline WP_006234103.1 & Hypothetical protein Colaer00186 & Collinsella aerofaciens & 0.0 & 95 \\
\hline AAS45464.1 & 6'-N-acetyltransferase & A. baumannii & $3 e^{-33}$ & 75 \\
\hline \multicolumn{5}{|c|}{ aac (6')-le-aph (2") } \\
\hline WP_002304968.1 & Phosphotransferase & E. faecium & $9 e^{-108}$ & 100 \\
\hline WP_001028140.1 & Acetyltransferase GNAT & S. aureus & $1 e^{-107}$ & 99 \\
\hline WP_001028143.1 & Acetyltransferase GNAT & S. aureus & $1 e^{-107}$ & 99 \\
\hline WP_010729367.1 & Bifunctional AAC/APH partial sequence & E. faecium & $5 e^{106}$ & 99 \\
\hline AAX82584.1 & Bifunctional AG modifying enzyme & Enterococcus faecalis & $2 e^{-112}$ & 100 \\
\hline WP_002417297.1 & 6' AG acetyltransferase & E. faecalis & $3 e^{-111}$ & 97 \\
\hline AFR11868.1 & $\begin{array}{c}\text { Bifunctional AG 6'-N acetytransferase/2'-AG } \\
\text { phosphotransferases }\end{array}$ & S. epidermidis & $1 e^{-43}$ & 99 \\
\hline AFM29914.1 & Gentamycin resistance protein & Enterococcus sp. & $7 e^{-45}$ & 97 \\
\hline \multicolumn{5}{|l|}{ aph (2") Id } \\
\hline 3SG8_A & $\begin{array}{c}\text { Chain A crystal structure AG 2' } \\
\text { phosphotransferases }\end{array}$ & E. casseliflavus & $1 e^{-110}$ & 98 \\
\hline 3N4T_A & Aph2" chain a & E. casseliflavus & $2 e^{-110}$ & 99 \\
\hline AAT77696.1 & AG modifying enzyme & E. faecium & $1 e^{-68}$ & 94 \\
\hline \multicolumn{5}{|l|}{ Aph (2")-Ic } \\
\hline 3TDVA & AG phosphotransferase & Enterococcus gallinarum & $2 e^{-83}$ & 97 \\
\hline \multicolumn{5}{|l|}{ ant (2") la } \\
\hline YP_005176240.1 & AG 2'-O-adenyltransferase & Pasturella mutocida & $2 e^{-97}$ & 100 \\
\hline WP_000314377.1 & 2' AG nucleotidlytransferase & A. baumannii & $3 e^{-94}$ & 99 \\
\hline WP_000946493.1 & $2^{\prime} A G$ & A. baumannii & $1 e^{-94}$ & 99 \\
\hline ACJ47203.1 & AG adenyltransferase & E. coli & $6 e^{-94}$ & 99 \\
\hline ACA48663.14 & AG adenyltransferase & Morganella morganii & $2 e^{-96}$ & 99 \\
\hline \multicolumn{5}{|l|}{$\operatorname{aac}(3)-\mathrm{VI}$} \\
\hline AAA16194.1 & aаc 3-6 & Enterobacter cloacae & $2 e^{-05}$ & 77 \\
\hline WP_001642188.1 & AG acetyltransferase & S. enterica subsp enterica & $2 e^{-20}$ & 98 \\
\hline
\end{tabular}

AG: aminoglycoside. Gene names are in bold.

significant attention due to their role in nosocomial infections [58,59]. Notably, the role of mobile genetic elements in the maintenance and dissemination of multi-drug resistance in Enterococcus faecalis and E. faecium has previously been highlighted $[30,60,61]$. While it is not certain that the genes identified in this study are also associated with mobile elements, the possibility that resistance genes could be transferred to commensals is a concern. Homologues of aminoglycoside adenylation genes, ant (2")-Ia, were also successfully detected. These resembled genes from Pasteurella, Acinetobacter and E. coli (Table 3), and the findings are thus consistent with previous research showing that these genes are most frequently detected in Gram negative bacteria [62]. Overall, the results demonstrate that the gut microbiota is a source of diverse aminoglycoside and $\beta$-lactam resistance genes, despite having had no recent antibiotic exposure. If these genes are expressed there is the potential that if antibiotic exposure occurred, bacteria containing these resistance genes would become the dominant component of the gut microbiota, as has been shown in previous studies $[5,63]$.

\section{Conclusions}

This study has highlighted the merits of applying a PCR-based approach to detect antibiotic resistance genes within the human gut microbiome. The results clearly demonstrate that the human gut microbiota is a considerable reservoir for resistance genes. Further studies are required to determine the exact sources of these genes and to determine if they have the potential to become mobile. Additionally, we have highlighted the successful application of a PCR-based screen of a complex environment without 
prior isolation of resistant isolates. The possibility exists to couple this approach with lower throughput next generation sequencing strategies, such as that provided by the Ion PGM 314 chip, in instances where great diversity is likely. Our approach could also be used in conjunction with functional screening of metagenomic libraries to enable the detection of genes present in a complex environment at a low threshold and that may have avoided capture in the metagenomic library, as shown in a recent study [64]. Such a PCR-based approach is not being proposed as a substitute for ultra-deep high-throughput shotgun sequencing of metagenomic DNA, rather it is a lower cost, more targeted, alternative which facilitates the detection and in silico analysis of specific gene sets of interest. Finally, while this study demonstrates that the gut microbiota is a source of diverse resistance genes, further studies are required to investigate the exact sources of these genes, their expression and whether they have the potential to become mobile. As the scientific community continues to gain knowledge with respect to the genetic mechanisms involved in providing resistance to various antibiotics, the design of additional sets of degenerate primers will be possible and will provide further opportunities for the use of PCR to rapidly and efficiently detect antibiotic resistance genes in complex microbial environments, including the human gut microbiota.

\section{Availability of supporting data}

The data sets supporting results of this article are available in the LabArchives repository, [http://dx.doi.org/10.6070/ H42V2D1V].

\section{Abbreviations \\ AAC: Acetylation enzymes; APH: Phosphorylation enzymes; ANT: Adenylation enzymes; ESBL: Extended spectrum $\beta$-lactamase; AG: Aminoglycoside.}

\section{Competing interests}

The authors declare that they have no competing interests.

\section{Authors' contributions}

FF conceived the study, was involved in the study design, performed the laboratory experiments and analysis and wrote the manuscript. RPR was involved in the study design and the drafting of the manuscript. GFF was involved in drafting of the manuscript. CS was involved in the study design and drafting of the manuscript. PDC conceived the study, was involved in the study design, interpretation of the data and drafting of the manuscript. All authors read and approved the final manuscript.

\section{Acknowledgements}

The authors wish to acknowledge the advice, assistance and protocols received from Dr. Brian Jones and Dr. Lesley Ogilvie regarding metagenomic sample preparation and analysis. Additionally the authors acknowledge the gift of control bacteria strains from the Smalla laboratory, JKI, Braunschweig. Fiona Fouhy is in receipt of an Irish Research Council EMBARK scholarship and is a Teagasc Walsh fellow. Research in the PDC laboratory is also supported by the Irish Government under the National Development Plan through the Science Foundation Ireland Investigator award 11/PI/1137.

\section{Author details}

${ }^{1}$ Teagasc Food Research Centre, Moorepark, Fermoy, Cork, Ireland. ${ }^{2}$ School of Microbiology, University College Cork, Cork, Ireland. ${ }^{3}$ Alimentary Pharmabiotic Centre, Cork, Ireland.

Received: 12 August 2013 Accepted: 3 February 2014 Published: 5 February 2014

\section{References}

1. Davies J, Davies D: Origins and evolution of antibiotic resistance. Microbiol Mol Biol Rev 2010, 74:417-433.

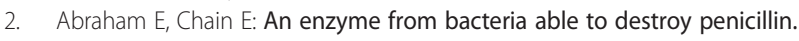
Nature 1940, 146:837-837.

3. Salyers AA, Gupta A, Wang Y: Human intestinal bacteria as reservoirs for antibiotic resistance genes. Trends Microbiol 2004, 12:412-416.

4. Broaders E, Gahan CG, Marchesi JR: Mobile genetic elements of the human gastrointestinal tract: potential for spread of antibiotic resistance genes. Gut microbes 2013, 4:271-280.

5. Dethlefsen $L$, Huse S, Sogin ML, Relman DA: The pervasive effects of an antibiotic on the human gut microbiota, as revealed by deep 16S rRNA sequencing. PLOS Biol 2008, 6:e280. 210.137/journal.pbio.0060280.

6. Cotter P, Stanton C, Ross R, Hill C: The impact of antibiotics on the gut microbiota as revealed by high throughput DNA sequencing. Discov Med 2012, 13:193-199.

7. Sommer MOA, Dantas G, Church GM: Functional characterization of the antibiotic resistance reservoir in the human microflora. Sci 2009, 325:1128-1131.

8. Mingeot-Leclercq MP, Glupczynski Y, Tulkens PM: Aminoglycosides: activity and resistance. Antimicrob Agents Chemother 1999, 43:727-737.

9. Page MGP: Beta-Lactam Antibiotics. Antibiot Discov Dev 2012, 1:79-117.

10. Tipper DJ, Strominger JL: Mechanism of action of penicillins: a proposal based on their structural similarity to acyl-D-alanyl-D-alanine. Proc Natl Acad Sci U S A 1965, 54:1133-1141.

11. Bush K: Characterization of beta-lactamases. Antimicrob Agents Chemother 1989, 33:259-263.

12. Bush K: Alarming beta-lactamase-mediated resistance in multidrug-resistant Enterobacteriaceae. Curr Opin Microbiol 2010, 13:558-564.

13. Kotra LP, Mobashery S: $\beta$-Lactam antibiotics, $\beta$-lactamases and bacterial resistance. Bull Inst Pasteur 1998, 96:139-150.

14. Tipper D: Mode of action of $\beta$-lactam antibiotics. Rev Infect Dis 1979, 1:39-53.

15. Hughes VM, Datta N: Conjugative plasmids in bacteria of the 'pre-antibiotic' era. Nature 1983, 302:725-726.

16. Bhullar K, Waglechner N, Pawlowski A, Koteva K, Banks ED, Johnston MD, Barton HA, Wright GD: Antibiotic resistance is prevalent in an isolated cave microbiome. PLOS ONE 2012, 7:e34953.

17. D'Costa VM, King CE, Kalan L, Morar M, Sung WWL, Schwarz C, Froese D, Zazula G, Calmels F, Debruyne R: Antibiotic resistance is ancient. Nature 2011, 477:457-461.

18. Dallenne C, Da Costa A, Decré D, Favier C, Arlet G: Development of a set of multiplex PCR assays for the detection of genes encoding important $\beta$-lactamases in Enterobacteriaceae. J Antimicrob Chemother 2010, 65:490-495.

19. Vannuffel P, Gigi J, Ezzedine H, Vandercam B, Delmee M, Wauters G, Gala J-L: Specific detection of methicillin-resistant Staphylococcus species by multiplex PCR. J Clin Microbiol 1995, 33:2864-2867.

20. Heuer H, Krögerrecklenfort E, Wellington E, Egan S, Elsas J, Overbeek L, Collard JM, Guillaume G, Karagouni A, Nikolakopoulou T: Gentamicin resistance genes in environmental bacteria: prevalence and transfer. FEMS Immunol Med Microbiol 2002, 42:289-302.

21. Eckburg PB, Bik EM, Bernstein CN, Purdom E, Dethlefsen L, Sargent M, Gill $\mathrm{SR}$, Nelson KE, Relman DA: Diversity of the human intestinal microbial flora. Science 2005, 308:1635-1638.

22. Bailey JK, Pinyon JL, Anantham S, Hall RM: Distribution of the blaTEM gene and blaTEM-containing transposons in commensal Escherichia coli. J Antimicrob Chemother 2011, 66:745-751.

23. Tenover FC, Huang MB, Rasheed JK, Persing DH: Development of PCR assays to detect ampicillin resistance genes in cerebrospinal fluid samples containing Haemophilus influenzae. Eur J Clin Microbiol 1994, 32:2729-2737 
24. Briñas $L$, Zarazaga $M$, Sáenz $Y$, Ruiz-Larrea $F$, Torres $C$ : $\beta$-Lactamases in ampicillin-resistant Escherichia coli isolates from foods, humans, and healthy animals. Antimicrob Agents Chemother 2002, 46:3156-3163.

25. Monstein H-J, Tärnberg M, Nilsson LE: Molecular identification of CTX-M and blaOXY/K1 $\beta$-lactamase genes in Enterobacteriaceae by sequencing of universal M13-sequence tagged PCR-amplicons. BMC Infect Dis 2009, 9:7-15.

26. De Fátima Silva Lopes M, Ribeiro T, Abrantes M, Figueiredo Marques JJ, Tenreiro R, Crespo MTB: Antimicrobial resistance profiles of dairy and clinical isolates and type strains of enterococci. Int J Food Microbiol 2005 103:191-198.

27. Schmitz F-J, Fluit AC, Gondolf M, Beyrau R, Lindenlauf E, Verhoef J, Heinz $\mathrm{H}-\mathrm{P}$, Jones ME: The prevalence of aminoglycoside resistance and corresponding resistance genes in clinical isolates of staphylococci from 19 European hospitals. J Antimicrob Chemother 1999, 43:253-259.

28. Matsumura M, Katakura Y, Imanaka T, Aiba S: Enzymatic and nucleotide sequence studies of a kanamycin-inactivating enzyme encoded by a plasmid from thermophilic bacilli in comparison with that encoded by plasmid pUB110. J bacteriol 1984, 160:413-420.

29. Ubukata K, Yamashita N, Gotoh A, Konno M: Purification and characterization of aminoglycoside-modifying enzymes from Staphylococcus aureus and Staphylococcus epidermidis. Antimicrob Agents Chemother 1984, 25:754-759.

30. Hegstad K, Mikalsen T, Coque T, Werner G, Sundsfjord A: Mobile genetic elements and their contribution to the emergence of antimicrobial resistant Enterococcus faecalis and Enterococcus faecium. Clin Microbiol Infect 2010, 16:541-554.

31. Ferretti JJ, Gilmore K, Courvalin P: Nucleotide sequence analysis of the gene specifying the bifunctional 6'-aminoglycoside acetyltransferase 2"-aminoglycoside phosphotransferase enzyme in Streptococcus faecalis and identification and cloning of gene regions specifying the two activities. J bacteriol 1986, 167:631-638.

32. Fouhy F, Ross RP, Fitzgerald GF, Stanton C, Cotter PD: PCR sequencing data of aminoglycoside and beta-lactam resistance genes. BMC microbiology 2013. http://dx.doi.org/10.6070/H42V2D1V; 2013.

33. Morris D, Whelan M, Corbett-Feeney G, Cormican M, Hawkey P, Li X, Doran G: First Report of Extended-Spectrum- $\beta$-Lactamase-Producing Salmonella enterica Isolates in Ireland. Antimicrob Agents Chemother 2006, 50:1608-1609.

34. Perilli M, Felici A, Franceschini N, De Santis A, Pagani L, Luzzaro F, Oratore A, Rossolini GM, Knox JR, Amicosante G: Characterization of a new TEM-derived beta-lactamase produced in a Serratia marcescens strain. Antimicrob Agents Chemother 1997, 41:2374-2382.

35. Zhao W-H, Hu Z-Q, Chen G, Matsushita K, Fukuchi K, Shimamura T: Characterization of imipenem-resistant Serratia marcescens producing IMP-type and TEM-type beta-lactamases encoded on a single plasmid. Microbiol Res 2007, 162:46-52.

36. Morosini MI, Canton R, Martinez-Beltran J, Negri MC, Perez-Diaz JC, Baquero F, Blazquez J: New extended-spectrum TEM-type beta-lactamase from Salmonella enterica subsp. enterica isolated in a nosocomial outbreak. Antimicrob Agents Chemother 1995, 39:458-461.

37. Wong MHY, Liu M, Wan HY, Chen S: Characterization of ExtendedSpectrum- $\beta$-Lactamase-Producing Vibrio parahaemolyticus. Antimicrob Agents Chemother 2012, 56:4026-4028.

38. Mokracka J, Koczura R, Kaznowski A: Multiresistant Enterobacteriaceae with class 1 and class 2 integrons in a municipal wastewater treatment plant. Water Res 2012, 46:3353-3363.

39. Coque TM, Oliver A, Pérez-Díaz JC, Baquero F, Cantón R: Genes Encoding TEM-4, SHV-2, and CTX-M-10 Extended-Spectrum $\beta$-Lactamases Are Carried by Multiple Klebsiella pneumoniae Clones in a Single Hospital (Madrid, 1989 to 2000). Antimicrob Agents Chemother 2002, 46:500-510.

40. Paterson DL, Hujer KM, Hujer AM, Yeiser B, Bonomo MD, Rice LB, Bonomo RA Extended-spectrum $\beta$-lactamases in Klebsiella pneumoniae bloodstream isolates from seven countries: dominance and widespread prevalence of SHV-and CTX-M-type $\beta$-lactamases. Antimicrob Agents Chemother 2003, 47:3554-3560.

41. Heritage J, M'Zali FH, Gascoyne-Binzi D, Hawkey PM: Evolution and spread of SHV extended-spectrum $\beta$-lactamases in Gram-negative bacteria. Journal of antimicrobial chemotherapy 1999, 44:309-318.
42. Babini GS, Livermore DM: Antimicrobial resistance amongst Klebsiella spp. collected from intensive care units in Southern and Western Europe in 1997-1998. J Antimicrob Chemother 2000, 45:183-189.

43. Pitout J, Sanders C, Sanders W Jr: Antimicrobial resistance with focus on beta-lactam resistance in gram-negative bacilli. Am J Med 1997, 103:51-59.

44. Bonnet R: Growing group of extended-spectrum $\beta$-lactamases: the CTX-M enzymes. Antimicrob Agents Chemother 2004, 48:1-14

45. Pitout JDD, Laupland KB: Extended-spectrum [beta]-lactamase-producing Enterobacteriaceae: an emerging public-health concern. Lancet Infect Dis 2008, 8:159-166

46. Coque T, Baquero F, Canton R: Increasing prevalence of ESBL-producing Enterobacteriaceae in Europe. Euro Surveillance 2008, 13:19-29.

47. CDC: Antibiotic resistance threats in the United States. 2013. Retrieved from www.cdc.gov/drugresistance/threat-report-2013/.

48. Boyd DA, Tyler S, Christianson S, McGeer A, Muller MP, Willey BM, Bryce E, Gardam M, Nordmann P, Mulvey MR: Complete nucleotide sequence of a 92-kilobase plasmid harboring the CTX-M-15 extended-spectrum beta-lactamase involved in an outbreak in long-term-care facilities in Toronto, Canada. Antimicrob Agents Chemother 2004, 48:3758-3764.

49. Lavollay M, Mamlouk K, Frank T, Akpabie A, Burghoffer B, Redjeb SB, Bercion $R$, Gautier V, Arlet G: Clonal dissemination of a CTX-M-15 $\beta$-lactamaseproducing Escherichia coli strain in the Paris area, Tunis, and Bangui. Antimicrob Agents Chemother 2006, 50:2433-2438.

50. Cho YJ, Moon DC, Jin JS, Choi CH, Lee YC, Lee JC: Genetic basis of resistance to aminoglycosides in Acinetobacter spp. and spread of armA in Acinetobacter baumannii sequence group 1 in Korean hospitals. Diagn Microbiol Infect Dis 2009, 64:185-190.

51. Lambert T, Gerbaud G, Courvalin P: Characterization of the chromosomal aac $\left(6^{\prime}\right)$-lj gene of Acinetobacter sp. 13 and the aac $\left(6^{\prime}\right)$-Ih plasmid gene of Acinetobacter baumannii. Antimicrob Agents Chemother 1994, 38:1883-1889.

52. Shaw K, Cramer C, Rizzo M, Mierzwa R, Gewain K, Miller G, Hare R: Isolation, characterization, and DNA sequence analysis of an AAC (6')-II gene from Pseudomonas aeruginosa. Antimicrob Agents Chemother 1989, 33:2052-2062

53. Park CH, Robicsek A, Jacoby GA, Sahm D, Hooper DC: Prevalence in the United States of aac $\left(6^{\prime}\right)$-lb-cr encoding a ciprofloxacin-modifying enzyme. Antimicrob Agents Chemother 2006, 50:3953-3955.

54. Dijkshoorn L, Nemec A, Seifert H: An increasing threat in hospitals: multidrug-resistant Acinetobacter baumannii. Nat Rev Microbiol 2007, 5:939-951.

55. Perez F, Hujer AM, Hujer KM, Decker BK, Rather PN, Bonomo RA: Global challenge of multidrug-resistant Acinetobacter baumannii. Antimicrob Agents Chemother 2007, 51:3471-3484.

56. Vakulenko SB, Donabedian SM, Voskresenskiy AM, Zervos MJ, Lerner SA, Chow JW: Multiplex PCR for detection of aminoglycoside resistance genes in enterococci. Antimicrob Agents Chemother 2003, 47:1423-1426.

57. Vanhoof R, Godard C, Content J, Nyssen H, Hannecart-Pokorni E: Detection by polymerase chain reaction of genes encoding aminoglycoside-modifying enzymes in methicillin-resistant Staphylococcus aureus isolates of epidemic phage types. J Med Microbiol 1994, 41:282-290.

58. Han D, Unno T, Jang J, Lim K, Lee S-N, Ko G, Sadowsky MJ, Hur H-G: The occurrence of virulence traits among high-level aminoglycosides resistant Enterococcus isolates obtained from feces of humans, animals, and birds in South Korea. Int J Food Microbiol 2011, 144:387-392.

59. Montecalvo MA, Horowitz H, Gedris C, Carbonaro C, Tenover FC, Issah A, Cook P, Wormser GP: Outbreak of vancomycin-, ampicillin-, and aminoglycoside-resistant Enterococcus faecium bacteremia in an adult oncology unit. Antimicrob Agents Chemother 1994, 38:1363-1367.

60. Leclercq R: Enterococci acquire new kinds of resistance. Clin Infect Dis 1997, 24:S80-S84.

61. McKay G, Thompson P, Wright G: Broad spectrum aminoglycoside phosphotransferase type III from Enterococcus: overexpression, purification, and substrate specificity. Biochemistry 1994, 33:6936-6944.

62. Shaw K, Rather P, Hare R, Miller G: Molecular genetics of aminoglycoside resistance genes and familial relationships of the aminoglycoside-modifying enzymes. Microbiol Rev 1993, 57:138-163. 
63. Fouhy F, Guinane CM, Hussey S, Wall R, Ryan CA, Dempsey EM, Murphy B, Ross RP, Fitzgerald GF, Stanton C: High-throughput sequencing reveals the incomplete, short-term, recovery of the infant gut microbiota following parenteral antibiotic treatment with ampicillin and gentamycin. Antimicrob Agents Chemother 2012, 56:5811-5820.

64. de Vries LE, Vallès Y, Agersø Y, Vaishampayan PA, García-Montaner A, Kueh $J$, Christensen H, Barlow M, Francino MP: The gut as reservoir of antibiotic resistance: microbial diversity of tetracycline resistance in mother and infant. PLOS ONE 2011, 6:e21644.

doi:10.1186/1471-2180-14-25

Cite this article as: Fouhy et al:: A degenerate PCR-based strategy as a means of identifying homologues of aminoglycoside and $\beta$-lactam resistance genes in the gut microbiota. BMC Microbiology 2014 14:25.

\section{Submit your next manuscript to BioMed Central and take full advantage of:}

- Convenient online submission

- Thorough peer review

- No space constraints or color figure charges

- Immediate publication on acceptance

- Inclusion in PubMed, CAS, Scopus and Google Scholar

- Research which is freely available for redistribution 